\title{
Bireylerin Mutlu Bir Romantik İlişside Partnerlerinden Beklediği Davranış/Durumların Sıralama Yargılarıyla Ölçeklenmesi
}

\section{Scaling the Behaviors/Situations That Individuals Expect from Their Partners in a Happy Romantic Relationship Through Rank-Order Judgments}

\author{
Duygu ANIL *, Sebahat GÖREN **
}

\begin{abstract}
Öz: Bu araştırmada "bireylerin mutlu bir romantik ilişkide partnerlerinden beklediği davranış/durumların" neler olduğu sıralama yargıları yöntemi ile ölçekleme çalışması yapılarak belirlenmeye çalışılmıştır. Ayrıca Türk ve Amerikalı katılımcılar için ülke değişkenine göre de ayrı ayrı ölçekleme çalışması yapılarak sıralamalar karşılaştırılmıştır. Araştırmanın verileri gönüllü 86 Amerikalı ve 113 Türk katılımcının kendi ana dillerinde hazırlanmış bir veri toplama aracına verdikleri cevaplardan oluşmaktadır. Araştırma bulgularına göre, katılımcıların mutlu bir romantik ilişkide partnerlerinden bekledikleri davranış/durumlardan en çok önemsenen üç tanesi "sorumluluklarını yerine getirmesi", "bana özgürlük alanı tanıyabilmesi" ve "görgü ve nezaket kurallarına uygun davranması" olarak belirlenmiştir. Bu sıralama, Amerikalı ve Türk katılımcılar için farklılık göstermiştir. Türk katılımcılar için ilk üç sırada "sorumluluklarını yerine getirmesi", "ailem ile iyi ilişkiler kurabilmesi”, "bana özgürlük alanı tanıyabilmesi" yer alırken; Amerikalı katılımcılar için bu sıra "sorumluluklarını yerine getirmesi", "bana özgürlük alanı tanıyabilmesi" ve "ihtiyaçlarımı kendi fark edip karşılaması" şeklinde olmuştur.

Anahtar Kelimeler: Mutlu romantik ilişki, sıralama yargıları yöntemi, ölçekleme, partnerden beklenilen davranışlar/durumlar
\end{abstract}

\begin{abstract}
In this study, it was studied to determine what the behaviors/situations that individuals expect from their partners in a happy romantic relationship should be by scaling study with the law of rank order judgment scaling model to determined. In addition, rankings were compared by conducting scaling study separately for Turkish and American participants according to country variable. Data set of the study consisted of 86 American and 113 Turkish volunteer participants' responses to a data collection tool prepared in their native language. According to the research findings. Three of the most important behaviors / situations expected from the partners in a happy romantic relationship were determined as "fulfills the responsibilities of a healthy relationship". "respects my personal freedom/space" and "follows the rules of etiquette and has good manners". This ranking was different for American and Turkish participants. On the other hand, for the Turkish participants first three criteria are stated as "fulfills the responsibilities of a healthy relationship", "has good relations with my parents", "respects my personal freedom/space"; for the American participants the order changes as "fulfills the responsibilities of a healthy relationship", "respects my personal freedom/space" and "realizes my needs and meets them".
\end{abstract}

Keywords: Happy romantic relationship, rank order judgment model, scaling, the behaviors/situations expected from partner

Giriş

Kişiden kişiye değişen, özgün bir kavram olan mutluluk, tarihin en eski yıllarından günümüze kadar farklı tanımlarla karşımıza çıkmıştır. Descartes mutluluğu, ruhsal memnuniyet ve içsel huzur olarak tanımlarken, doğru bilginin mutluluğa ulaşmak için ilk şart olduğunu belirtmiştir

\footnotetext{
* Prof. Dr. Duygu ANIL, Hacettepe Üniversitesi, Eğitim Bilimleri Bölümü, Eğitimde Ölçme ve Değerlendirme Anabilim Dalı, Ankara, Türkiye; ORCID: 0000-0002- 1745-4071; duygu.anil73@gmail.com

**Arş. Gör. Sebahat GÖREN, Hacettepe Üniversitesi, Eğitim Bilimleri Bölümü, Eğitimde Ölçme ve Değerlendirme Bilim Dalı, Ankara, Türkiye; ORCID: 0000-0002-6453-3258;sebahatgoren@ gmail.com
} 
(Türkben, 2010). Aristo ise mutluluğa ulaşmak için iyiliğin olması gerektiğini savunurken, mutluluğun tartışmalı bir konu olduğunu belirtmiştir (Tuncer, 2006). Schopenhauer, mutluluğu "mutsuz olmama hali" olarak tanımlamıştır. Aristo mutluluğu etkinlik olarak tanımlarken, Schopenhauer gibi düşünürler bir duygu olarak tanımlamıştır. Farabi' ye göre mutluluk insanların ulaşmayı hedeflediği genel bir amaçtır (Farabi, 1993). Tam ve mutlak olarak kuralları olmayan mutluluk, bireyin yaşamındaki olumlu duygu ve düşüncelerin nicelik olarak üstünlüğü şeklinde tanımlanmıştır (Myers ve Diener, 1995). Doğan (2013) mutluluğu, keyif veren pozitif duyguların daha çok, acı ve kasvet veren negatif duyguların ise daha seyrek yaşanması olarak ifade ederken; Aluş (2016), bireylerin hayatları boyunca yaşamak istedikleri ve buna ulaşmak için çaba gösterdikleri, sonucunda da kişide hoşnutluk yaratan biyolojik ve psikolojik bir durum olarak ifade etmiştir. Görüldüğü üzere tarih boyunca mutluluğun üzerinde hem fikir olunduğu ortak bir tanımlaması yapılamamıştır.

Geçmişten günümüze yapılan tanımlardan da anlaşılacağı üzere şüphesiz her birey mutlu olmak ister. Çünkü mutlu olmak bireyin iyi hissetmesini ve ruhsal açıdan olumlu olmasını sağlarken; mutsuzluk hali ise ruhsal işlevleri azaltıcı olarak etki gösterebilmektedir (Fromm, 2003). İnsanoğlunun en temelde ihtiyaç duyduğu olgu olan mutluluk(Gilman, Huebner ve Laughlin, 2000) yaşamın her anını etkileyebilen ve farklı kılabilen bir potansiyele sahiptir. Özellikle insanlar yalnız yaşayamayan başkalarıyla sürekli yakın ilişki içerisinde olan canlılar olduğundan mutluluk olgusu da bireylerin kurduğu bu ilişkilere doğrudan etki etmektedir. Bu yakın ilişkilerden biri de kişinin hayatında önemli bir yer kaplayan partnerleriyle kurmuş oldukları romantik ilişkilerdir. Collins (2003) romantik ilişkiyi her iki tarafın gönüllü olduğu ve karşılıklı olarak kabul ettiği bir ilişki türü olarak tanımlamakta ve romantik ilişkinin önemli boyutlarından birinin de bilişsel ve duyuşsal süreçler olduğunu vurgulamaktadır. Bu bilişsel ve duyuşsal özellikler, kişilerin ilişkiye ve partnerlerine yönelik algılarını, duygusal tepkilerini ve beklentilerini ifade etmektedir (Collins, 2003). Mutluluk kavramının tanımından yola çıkarak mutlu bir romantik ilişki, kişinin kendisine keyif veren pozitif duyguların hissedildiği, içsel huzurun sağlandığı, yaşamak istenilen ve olması gereken ilişki olarak tanımlanabilir. Bireylerin birbirlerinin beklentilerini bilmesi ve ona uygun davranması şüphesiz mutlu bir romantik ilişkinin zeminini oluşturacaktır. Bireyler her zaman mutlu bir romantik ilişki içerisinde olmayabilirve kimi zaman ilişkiyi yürütemeyecek düzeyde sağlıksız ve mutsuz ilişkiler yaşayabilmektedir.

Bireyler arasında kurulan mutlu romantik ilişkiler çoğunlukla kişinin özgürce seçtĭgi, tutku, bağlanma ve yakınlıkla betimlenen bir birliktelik olarak kavramlaştırılmaktadır (Sternberg, 1986). Mutlu bir romantik ilişkide ise çiftlerin birbirlerini memnun edebilmeleri en temel ve önemli konulardan biridir. Çünkü ilişkilerde yaşanan mutluluğun genel mutluluğa, hayatın diğer alanlarından daha fazla katkıda bulunduğu söylenebilir. Romantik ilişkilerde partnerler; güven, rahatlama ve desteğin en önemli kaynağıdır (Hazan ve Zeifman, 1999). Bireyin biricik olma özelliğinden ötürü mutlu bir ilişkide bireylerin partnerlerinden beklentileri de farklı olabilmektedir. Bazı insanlar ilişkilerinde sahiplenilmeyi isterken, bazıları ise özgür olmayı daha çok istemektedir. Bazıları fiziksel özellikleri ön planda tutarken, bazıları kariyer sahibi bir partneri tercih edebilmektedir. Tüm bu istekler bireyin yaşam sürecinde elde ettiği tecrübelere bağlı olarak şekillenir (Aydoğdu, 2010). Sonuç olarak mutlu bir ilişkide partnerlerin birbirlerinden bekledikleri davranış veya durumlar da mutluluk olgusu gibi durumdan duruma hatta kişiden kişiye değişiklik gösterebilmektedir.

Genellikle literatüre bakıldığında eş seçiminde bireylerin dikkat ettikleri özellikler ve mutlu evlilikle ilgili yapılan çalışmalar dikkat çekmektedir. Osmond (1977) tarafından yapılan araştırmada mutlu evlilikleri olan çiftlerin karar vermede birlikte davrandıkları, partnerlerden birinin kararlarda daha baskın olmaya çalışmasının evlilik doyumunu azalttığını ve boşanmaları arttırdığını belirtmiştir. Hoyt ve Hudson (1981), eş seçiminde erkek öğrencilerin istedikleri üç özelliği önem derecesine göre güvenilir karaktere sahip olma, duygusal kararlılık ve hoş görünüm olarak sıralarken; kız öğrenciler istedikleri üç özelliği duygusal kararlılık, güvenilir karaktere sahip olma, hırslı ve çalışkan olma olarak sıralamıştır. Toro-Morn ve Sprecher (2003), bireylerin $A B D$ ve Çin kültürlerinde eş adayı tercihlerini karşılaştırmalı olarak inceledikleri çalışmada; fiziksel çekicilik, iyi maddi gelire sahip olma, nazik olma gibi özellikler ön plana çıkmıştır. Efe'ye 
(2013) göre eş tarafından sevilme, eşin dürüst, güvenilir, sadık, saygıl1, sorumluluk sahibi, ruhen sağlıklı, hoşgörülü, temiz/bakımlı ve merhametli olması gibi özellikler eş tercihinde sırasıyla 50 özellikten ilk 10 sırada yer almaktadır. Uraz'ın (1979) üniversite öğrencilerinin eşlerinden beklentilerini incelediği araştırmada erkeklerin fiziksel özellikler ve manevi değerlere daha çok önem verdiği saptanmıştır. Kocadere' nin (1995) iyi ve kötü evliliklerin özelliklerini belirlemeye yönelik yaptığı araştırmada; kötü evliklerde eşlerin birbirlerinin ailesiyle anlaşamama durumunun iyi evliliklerden dört kat daha fazla olduğu, iyi evliliklerdeki eşlerin daha çok birlikte vakit geçirdiği, çocuğun evliliğin iyi ya da kötü değerlendirilmesinde etkisinin olmadığı, kötü evliliklerde maddi sorunların ciddi problemlere yol açtığı, iyi evliliklerde eslerin duygu ve düşünce paylaşımlarının daha çok olduğu, kötü evliliklerde kararların daha çok tek taraflı alındığı iyi evliliklerde ise kararların ortak alındığı sonucuna ulaşmıştır. Görüldüğ̈̈ üzere, alan yazın incelendiğinde, evlilik öncesi romantik ilişkilere daha az odaklanıldığı görülmektedir. Oysaki günümüzde gençlerin evlilik öncesi dönemdeki romantik ilişkilerde eskisine göre çok daha fazla zaman harcadıkları gözlenmektedir (Furstenberg, 2010). Psikolojik yardıma ihtiyaç duyan erişkinlerde en sık karşılaşılan sorunlardan birinin ilişki sorunları olduğu vurgulanmaktadır (Revenson, Kayser ve Bodenmann, 2005). Literatürde ise mutlu bir romantik ilişkide partnerlerin birbirinden beklediği davranışlar ile ilgili çalışmalara rastlanmamıştır.

Stevens'a (1966) göre ölçekleme, fiziksel objelerin yani çoğunlukla tutumların veya inançların bir kural dâhilinde sayılarla eşleştirilmesidir. Psikolojinin bir alt dalı olan psikofizikte ortaya çıkan ölçeklemede asıl amaç uyarıcıların ölçülen özellikleri ile algılanan özellikleri arasında bir bağlantı kurmaktır (Dunn-Runkin,1982; Guilford, 1954). Mutlu bir romantik ilişkide bireylerin partnerlerinden bekledikleri durum/davranışların belirlenmesinde, fiziksel dünya ile alg1 dünyası arasında nicel bir karşılaştırma yapmak için ölçeklemeden yararlanılmıştır. Çünkü ancak ölçekleme yardımı ile algılanan büyüklük ile gerçek büyüklük arasındaki ilişki kurallara bağlı nicel olarak ifade edilir (Anıl ve İnal, 2017). Ölçeklemede kullanılan deneysel yöntemler probleme uygulanan yaklaşıma göre "uyarıcı merkezli yaklaşım" ya da "yargı yaklaşımı" ve "tepki yaklaşımı" olmak üzere başlıca iki grupta toplanabilir (Anıl ve İnal, 2017). Yarg1 yaklaşımında yargıda bulunan kişiler kendi tepkilerini belirten denek durumunda olduğundan buradaki amaç denekler tarafından her uyarıcının ölçekleme boyutundaki yerinin aynı boyuttaki kendi yerine göre belirlenmesidir (Anıl ve Güler, 2006). Yarg1 yaklaşımından sıralama ise pek çok alanda uygulama yeri bulunan bir ölçme yöntemi olup gözlemciyi uyarıcılar arasında mümkün olan en büyük ayrımı yapmaya zorladığında, gözlemcinin bu ayrımı yapabildiği hallerde geçerliği çok yüksek bir ölçek vermektedir (Anıl ve İnal. 2017; Turgut ve Baykul 1992). Sıralama yargılarıyla ölçeklemede, uyarıcılar gözlemcilere ikişer ikişer değil de toplu halde verildiğinden bu yöntem ikili karşılaştırma yöntemine göre daha pratik bir yöntemdir. Fakat alanyazında sıralama yargılarıyla yapılan ölçekleme çalışmalarının(örn: Bal, 2011; Bozgeyikli, Derin ve Toprak 2016; Özkan ve Arslantaş, 2013) sayıca az olduğu görülmektedir.

Bu çalışmada son yıllarda hızla artan mutluluk kavramına ilişkin alan yazında ölçekleme ile ilgili az sayıda akademik çalışma bulunan sıralama yargıları yöntemi ile bireylerin mutlu bir romantik ilişkide partnerlerinden bekledikleri davranışların sıralanmasına yer verilmektedir. Ayrıca bu alanda yapılan araştırmaların gerek farklı kültürlerde gerekse Türkiye'de belirli aralıklarla tekrarlanmasının değişimleri izlemek açısından ilgili literatüre katkı sağlayacağı düşünülmüştür.

\section{Çalışmanın amacı ve önemi}

Bu çalışmanın amacı bireylerin mutlu bir ilişkide partnerlerinden beklediği davranış/durumların neler olduğunun ölçekleme yöntemlerinden biri olan siralama yargıları yöntemi ile belirlenmesidir. Ek olarak kültürler arası benzerlik ve farklılıkları görmek amacıyla Türk ve Amerikalı bireylerin mutlu bir ilişkide partnerlerinden bekledikleri durum/davranışların önem sırasına göre nasıl sıralandığı araştırılmıştır. Bu amaçla çalışmanın araştırma soruları aşağıdaki gibi sıralanabilir: 
1. Bireylerin mutlu bir ilişkide partnerlerinden bekledikleri davranışlar/durumlar sıralama yargılarına dayalı ölçekleme yöntemi ile elde edilen ölçek değerleri ve sıralamaları nasildır?

2. Türk katılımcıların mutlu bir ilişkide partnerlerinden bekledikleri davranışlar/durumlar için sıralama yargılarına dayalı ölçekleme yöntemi ile elde edilen ölçek değerleri ve siralamaları nasıldır?

3. Amerikalı katılımcıların mutlu bir ilişkide partnerlerinden bekledikleri davranışlar/durumlar için sıralama yargılarına dayalı ölçekleme yöntemi ile elde edilen ölçek değerleri ve sıralamaları nasıldır?

Alan yazında romantik ilişkilerle ilgili genellikle eş seçimi (Bozgeyikli ve Toprak, 2013; Hoyt ve Hudson, 1981; Shipman, 2011;Toro-Morn ve Sprecher, 2003; Yıldırım, 2007) ve mutlu evlilikle ilgili çalışmalar (Kocadere, 1995; Osmond, 1977; Toro-Morn ve Sprecher 2003) yer almaktadır. Evlilik öncesi romantik ilişkilere daha az odaklanıldığ görülmektedir. Fakat üniversite öğrencilerinin çoğunun romantik ilişkilerde yaşadıkları zorluklar sebebiyle üniversite psikolojik danışma merkezlerine başvurdukları bilinmektedir (Creasey, Kershaw ve Boston, 1999). Günümüzde gençlerin evlilik öncesi dönemde romantik ilişkilerde eskisine göre çok daha fazla zaman harcadıkları da gözlenmektedir (Furstenberg, 2010). Huston ve Levinger'e (1978) göre romantik ilişkilerin gelişimi, partnerlerin duygusal ve bilişsel yapıları haricinde kültürel ve sosyal özelliklerine göre de değişkenlik gösterebilmektedir. Romantik ilişkilerin yorumlanmasında bireylerin yetiştikleri kültürlerin de dikkate alınması gerekmektedir (Huston ve Levinger, 1978). Bu nedenle bu çalışma, bireylerin mutlu bir ilişkide partnerlerinden bekledikleri davranışların belirlenmesi amacıyla hem Türk hem de Amerikalı bireylerle birlikte yürütülmüştür.

$\mathrm{Bu}$ çalışmada bireylerin mutlu bir ilişkide partnerlerinden bekledikleri davranış/durumların neler olduğu belirlendiğinden oldukça orijinal bir konu üzerinde çalışılmış ve böylece alan yazında yapılacak mutlu ilişki kavramına ilişkin çalışmalara farklı bir bakış açısı katacağı beklenmektedir Ayrıca bu davranışlar sıralama yargıları yöntemi ile nicel olarak belirlendiğinden bu çalışmanın ölçekleme alanında yapılan çalışmalara katkı sağlayacağı düşünülmektedir. Ek olarak bu çalışma, ülkeler arası karşılaştırmalar yaparak mutlu bir ilişkide bireylerin birbirlerinden beklediği davranışların kültürler arası değişip değişmediğini gözlemleme firsatı sunmaktadır.

\section{Yöntem}

\section{Araştırmanın türü}

$\mathrm{Bu}$ çalışma, bireylerin mutlu bir ilişkide partnerlerinden bekledikleri davranış/durumların neler olduğunu ölçekleme yöntemlerinden sıralama yargılarıyla belirlenmesini ve sıralanmasını amaçlamıştır. Bu çalışma, örneklem bilgilerinden bir evrene genelleme yapmadığından ve mevcut durumu olduğu gibi ortaya koymayı amaçladığından betimsel bir çalışmadır (Karasar, 2013).

\section{Çalışma grubu}

Araştırma, gönüllülük esasına dayalı 20-40 yaş aralığında ulaşılabilen Amerikalı ve Türk bireyler ile yürütülmüştür. Çalışma grubu, 86 Amerikalı ve 113 Türk olmak üzere toplam 199 katılımcıdan oluşmaktadır. Çalışma grubundaki 199 kişiden 79'u erkek, 120' si kadındır. 113 Türk katılımcıdan 68'i kadın, 45'i erkek ise; 86 Amerikalı katılımcıdan 52'si kadın, 34'ü erkektir. Çalışma grubundaki 199 kişiden 135'i romantik ilişkide olduğunu belirtirken 64'ü romantik ilişkisi olmadığını belirtmiştir. 113 Türk katılımcıdan 77'si romantik ilişkide olduğunu belirtirken, 36'sı bir ilişkisi olmadığını belirtmiştir. 86Amerikalı katılımcıdan 58'i romantik ilişkide olduğunu belirtirken, 28'i bir ilişkisi olmadığını belirtmiştir.

\section{Veri toplama aracı}

Bireylerin mutlu bir romantik ilişkide partnerlerinden bekledikleri davranış/durumları sıralama yargıları yöntemine göre ölçeklemek amacıyla araştırma sürecinde Türkçe ve İngilizce dillerinde 
iki bölümden oluşan bir veri toplama aracı geliştirilmiştir. Birinci bölümde demografik bilgilerin sorgulandığ 1 maddeler, ikinci bölümde ise bireylerin mutlu bir ilişkide partnerlerinden bekledikleri 12 davranış/durum maddeleri yer almaktadır. Aracın geliştirilme sürecinde 20 Türk ve Amerikalı katılımcılardan oluşan pilot bir uygulama yapılmıştır. Bu pilot uygulamada katılımcılardan mutlu bir ilişkide partnerlerinden bekledikleri davranış/durumları bir liste yapmaları istenmiş̧ir. Elde edilen yanıtlar ve alan yazın (Efe, 2013; Hoyt ve Hudson,1981; Kocadere, 1995; Osmond, 1977; Toro-Morn ve Sprecher, 2003; Uraz, 1979) incelenmiş ve bireylerin mutlu bir ilişkide partnerlerinden bekledikleri davranış/durumlardan en çok önemsendiği düşünülen 12 durum/davranış belirlenmiştir. Bu 12 durum/davranışların en önemlisi 1 en önemsizi 12 olacak şekilde sıraya konulmasına izin verebilecek uygulama formatına geliştirilmiştir. Veri toplama aracı, ölçme ve değerlendirme, PDR uzmanı bulunan akademisyenler tarafindan incelenmiş ve gerekli düzenlemeler yapılarak güncellenmiştir. İngilizce ve Türkçe formlarının dil eşdeğerliği uzman kanılara dayalı olarak elde edilmiş olup çevirmenlerin ve akademisyenlerin değerlendirmeleri sonucunda alınan ortak karar ile İngilizce formlar oluşturulmuştur. Böylece dil eşdeğerliği yargısal olarak değerlendirilmiş ve formların uzmanlar tarafından dil eşdeğerliğinin uygun bulunduğu sonucuna ulaşılmıştır.

\section{Verilerin analizi}

Verilerin analizinde, birçok alanda uygulama yeri bulunan ve eldeki uyarıcıları gözlemcilerin yargılarına göre belirli bir boyutta ölçekleyen yargı yaklaşımlarından sıralama yargılarıyla ölçekleme yöntemi kullanılmıştır. Bu yöntem, gözlemciyi uyarıcılar arasında mümkün olan en büyük ayrımı yapmaya zorladığından, gözlemcinin bu ayrımı yapabildiği hallerde geçerliği çok yüksek bir ölçek sunmakta ve bir sıra numarası verilebilecek tüm uyarıcılara uygulanabilmektedir (Anıl ve İnal, 2017; Turgut ve Baykul, 1992). Yargıların toplanması için Türk ve Amerikalı bireylerin mutlu bir ilişkide partnerlerinden bekledikleri davranış/durumları sıralama yargılarına göre ölçeklendiği 12 davranış/durum (uyarıc1) verilmiştir. Bireylerden tüm davranış ve durumları düşünerek kendileri için en önemli davranış/durumdan (1) en az önemli davranış/duruma (12) doğru sıra numaraları vermeleri istenmiştir. Bu işlem sonucunda elde edilen verilerin tümü sıralama yargıları yöntemi ile Microsoft Excel programında çözümlenerek ölçek değerleri elde edilmiştir.

Çalışmanın analizinde ilk olarak bireylere yapmış oldukları sıralamalara ait frekans değerleri belirlenmiş ve frekans matrisi (F) oluşturulmuştur. Sıra frekansları yardımıyla her bir uyarıcının kendisi dışındaki uyarıcılarla ikili karşılaştırması;

$$
\boldsymbol{n}\left(\boldsymbol{S}_{\boldsymbol{j} i}>\boldsymbol{S}_{\boldsymbol{k} i}\right)=\boldsymbol{f}_{\boldsymbol{j} i} \cdot\left(\boldsymbol{f}_{\boldsymbol{k}<i}+\frac{\mathbf{1}}{\mathbf{2}} \cdot \boldsymbol{f}_{\boldsymbol{k} i}\right)(1)
$$

(1) denklemi kullanılarak her bir uyarıcı için frekanslar matrisi oluşturulmuştur. Burada j ve $\mathrm{k}$ uyarıcı numaraları, $i$ ise sıralamada verilen değerdir. Oluşturulan $n\left(S_{\mathrm{ji}}>S_{\mathrm{ki}}\right)$ frekansları matrisinin sütunlarında yer alan tüm satırların toplanması ile elde edilen frekanslar $\mathrm{N}^{2}$,ye bölünmüsstür. Böylece oranlar matrisi $(\mathrm{P})$ elde edilmiştir. Oranlar matrisindeki hücre değerlerine $(\mathrm{P})$ karşllık gelen $(Z)$ standart değerleri belirlenerek birim normal sapmalar matrisi elde edilmiştir. Matrisin sonunda her bir sütuna ait değerlerin toplamını gösteren bir satır oluşturulmuştur. Bu satırdaki her bir z hücre değerinin sütunlar boyunca ortalamaları alınmış ve ölçek değerleri $\left(\mathrm{S}_{\mathrm{j}}\right)$ hesaplanmıştır $S_{j}$ değerleri en küçük $S_{j}$ değeri sıfır olacak şekilde kaydırılarak $S_{c}$ ölçek değerleri bulunur (Anıl ve İnal, 2017; Güler ve Anıl, 2009).

\section{Bulgular}

$\mathrm{Bu}$ bölümde Türk ve Amerikalı bireylerin mutlu bir ilişkide partnerlerinden bekledikleri davranış/durumların sıralama yargılarına göre ölçeklenmesi sonucu elde edilen bulgu ve yorumlara yer verilmiştir. Her bir araştırma sorusuna yönelik sonuçlar sırasıyla aşağıda yer almaktadir.

\section{Birinci araştırma sorusuna ait bulgular}


Türk ve Amerikalı katılımcılardan mutlu bir ilişkide partnerlerinden bekledikleri 12 tane davranış/durumu sıralamaları istenmiştir. Yapılan sıralama sonrası bu davranış/durumlara ilişkin frekans değerleri belirlenerek Tablo 1'de gösterilmiştir.

Tablo 1.

Katılımcılara Ait Sira Frekansları Matrisi (F)

\begin{tabular}{lllllllllllllll}
\hline $\mathrm{Ri}$ & $\mathrm{ri}$ & $\mathrm{A}$ & $\mathrm{B}$ & $\mathrm{C}$ & $\mathrm{D}$ & $\mathrm{E}$ & $\mathrm{F}$ & $\mathrm{G}$ & $\mathrm{H}$ & $\mathrm{I}$ & $\mathrm{J}$ & $\mathrm{K}$ & $\mathrm{L}$ & Toplam \\
\hline 1 & 12 & 19 & 4 & 7 & 17 & 7 & 31 & 13 & 11 & 12 & 5 & 27 & 46 & 199 \\
2 & 11 & 17 & 8 & 2 & 18 & 11 & 11 & 25 & 9 & 21 & 22 & 43 & 12 & 199 \\
3 & 10 & 6 & 7 & 15 & 7 & 14 & 14 & 18 & 16 & 26 & 43 & 15 & 18 & 199 \\
4 & 9 & 7 & 4 & 8 & 14 & 15 & 12 & 18 & 17 & 50 & 19 & 22 & 13 & 199 \\
5 & 8 & 11 & 7 & 7 & 12 & 12 & 12 & 24 & 47 & 11 & 21 & 23 & 12 & 199 \\
6 & 7 & 9 & 5 & 6 & 11 & 18 & 18 & 42 & 17 & 26 & 20 & 20 & 7 & 199 \\
7 & 6 & 21 & 9 & 5 & 11 & 22 & 36 & 15 & 27 & 23 & 16 & 7 & 7 & 199 \\
8 & 5 & 10 & 12 & 15 & 15 & 48 & 21 & 14 & 21 & 3 & 20 & 12 & 8 & 199 \\
9 & 4 & 15 & 16 & 22 & 36 & 28 & 13 & 9 & 10 & 12 & 4 & 9 & 25 & 199 \\
10 & 3 & 23 & 28 & 48 & 16 & 13 & 17 & 3 & 11 & 4 & 15 & 4 & 17 & 199 \\
11 & 2 & 28 & 62 & 26 & 19 & 4 & 9 & 12 & 6 & 6 & 6 & 9 & 12 & 199 \\
12 & 1 & 33 & 37 & 38 & 23 & 7 & 5 & 6 & 7 & 5 & 8 & 8 & 22 & 199 \\
\hline \multicolumn{2}{l}{ Toplam } & 199 & 199 & 199 & 199 & 199 & 199 & 199 & 199 & 199 & 199 & 199 & 199 & \\
\hline
\end{tabular}

Tablo 1'de görüldüğü gibi uyarıcı sayısı 12 olup sıra frekansları matrisinin her bir satır ve sütun elemanlarının toplamı, toplam gözlemci sayısı olan 199'u verir.

Tablo 1'deki sıra frekansları yardımıyla her bir uyarıcı için $n\left(S_{j i}>S_{k i}\right)=f_{j i .} .\left(f_{k<i}+(1 / 2) \cdot f_{k i}\right.$ denklemi yardımıyla frekanslar matrisi oluşturulmuştur. Her bir uyarıcıya ilişkin frekanslar matrisi oluşturduktan sonra bu matrislerin sütun toplamları yardımı ile elde edilen oranlar matrisi Tablo 2‘de sunulmuştur.

Tablo 2.

Tüm Katılımcılara Ait Oranlar Matrisi (P)

\begin{tabular}{llllllllllll}
\hline & $\mathrm{A}$ & $\mathrm{B}$ & $\mathrm{C}$ & $\mathrm{D}$ & $\mathrm{E}$ & $\mathrm{F}$ & $\mathrm{G}$ & $\mathrm{H}$ & $\mathrm{I}$ & $\mathrm{J}$ & $\mathrm{K}$ \\
\hline $\mathrm{A}$ & & 0.376 & 0.420 & 0.540 & 0.589 & 0.642 & 0.668 & 0.641 & 0.697 & 0.659 & 0.708 \\
$\mathrm{~B}$ & 0.624 & & 0.557 & 0.678 & 0.760 & 0.789 & 0.806 & 0.792 & 0.832 & 0.801 & 0.829 \\
$\mathrm{C}$ & 0.580 & 0.443 & & 0.635 & 0.718 & 0.748 & 0.771 & 0.751 & 0.800 & 0.767 & 0.801 \\
$\mathrm{D}$ & 0.460 & 0.322 & 0.365 & & 0.556 & 0.611 & 0.641 & 0.610 & 0.673 & 0.634 & 0.688 \\
$\mathrm{E}$ & 0.411 & 0.240 & 0.282 & 0.444 & & 0.582 & 0.643 & 0.597 & 0.686 & 0.633 & 0.697 \\
$\mathrm{~F}$ & 0.359 & 0.211 & 0.252 & 0.389 & 0.418 & & 0.550 & 0.506 & 0.588 & 0.539 & 0.607 \\
$\mathrm{G}$ & 0.332 & 0.194 & 0.229 & 0.359 & 0.357 & 0.450 & & 0.449 & 0.548 & 0.502 & 0.589 \\
$\mathrm{H}$ & 0.359 & 0.208 & 0.249 & 0.390 & 0.403 & 0.494 & 0.551 & & 0.612 & 0.559 & 0.636 \\
$\mathrm{I}$ & 0.303 & 0.168 & 0.200 & 0.327 & 0.314 & 0.412 & 0.452 & 0.388 & & 0.462 & 0.552 \\
$\mathrm{~J}$ & 0.341 & 0.199 & 0.233 & 0.366 & 0.367 & 0.461 & 0.498 & 0.441 & 0.538 & & 0.590 \\
$\mathrm{~K}$ & 0.292 & 0.171 & 0.199 & 0.312 & 0.303 & 0.393 & 0.411 & 0.364 & 0.448 & 0.410 & \\
$\mathrm{~L}$ & 0.383 & 0.267 & 0.302 & 0.414 & 0.446 & 0.504 & 0.516 & 0.486 & 0.542 & 0.511 & 0.569 \\
\hline
\end{tabular}

Tablo 2'de görüldüğ̈̈ gibi frekans matrislerindeki sütun toplamları toplam kişi sayısının karesine $\left(\mathrm{N}^{2}=199^{2}\right)$ bölünerek Tablo 3'teki oranlar matrisi elde edilmiştir. Bu oranlar matrisinin esas köşegene göre simetrik olan elemanlarının toplamı 1'i vermektedir. Daha sonra oranlar matrisindeki hücrelerde yer alan değerlere karșllık gelen birim normal değerler ( $\mathrm{z}$ değerleri) elde edilmiş ve birim normal sapmalar matrisi $(Z)$ Tablo 3'te gösterilmiştir. Matristeki z sütun değerlerinin ortalamaları alınarak 12 'ye bölünmüş ve böylece ölçek değerleri $\left(\mathrm{S}_{\mathrm{j}}\right)$ hesaplanmıştır. 
Bireylerin Mutlu Bir Romantik İlişkide Partnerlerinden Beklediği Davranış/Durumların Sıralama Yargılarılla Ölçeklenmesi

Tablo 3.

Tüm Katılımcılara Ait Birim Normal Sapmalar Matrisi (Z)

\begin{tabular}{|c|c|c|c|c|c|c|c|c|c|c|c|c|}
\hline & A & B & $\mathrm{C}$ & $\mathrm{D}$ & E & $\mathrm{F}$ & $\mathrm{G}$ & $\mathrm{H}$ & I & $\mathrm{J}$ & $\mathrm{K}$ & $\mathrm{L}$ \\
\hline & & - & - & & & & & & & & & \\
\hline A & & 0.316 & 0.203 & 0.101 & 0.226 & 0.363 & 0.435 & 0.362 & 0.516 & 0.410 & 0.547 & 0.298 \\
\hline B & 0.316 & & 0.142 & 0.461 & 0.706 & 0.802 & 0.865 & 0.812 & 0.963 & 0.847 & 0.950 & 0.622 \\
\hline \multirow[t]{2}{*}{$\mathrm{C}$} & 0.203 & 0.142 & & 0.346 & 0.576 & 0.669 & 0.743 & 0.678 & 0.841 & 0.729 & 0.845 & 0.519 \\
\hline & - & - & - & & & & & & & & & \\
\hline \multirow[t]{2}{*}{$\mathrm{D}$} & 0.101 & 0.461 & 0.346 & & 0.141 & 0.282 & 0.361 & 0.279 & 0.449 & 0.342 & 0.490 & 0.217 \\
\hline & - & - & - & - & & & & & & & & \\
\hline \multirow[t]{2}{*}{ E } & 0.226 & 0.706 & 0.576 & 0.141 & & 0.207 & 0.367 & 0.247 & 0.484 & 0.340 & 0.516 & 0.135 \\
\hline & - & - & - & - & - & & & & & & & \\
\hline \multirow[t]{2}{*}{$\mathrm{F}$} & 0.363 & 0.802 & 0.669 & 0.282 & 0.207 & & 0.125 & 0.015 & 0.222 & 0.098 & 0.272 & 0.040 \\
\hline & - & - & - & - & - & - & & - & & & & \\
\hline \multirow[t]{2}{*}{ G } & 0.435 & 0.865 & 0.743 & 0.361 & 0.367 & 0.125 & & 0.128 & 0.120 & 0.006 & 0.225 & 0.040 \\
\hline & - & - & - & - & - & - & & & & & & \\
\hline \multirow[t]{2}{*}{$\mathrm{H}$} & 0.362 & 0.812 & 0.678 & 0.279 & 0.247 & 0.015 & 0.128 & & 0.286 & 0.149 & 0.347 & 0.106 \\
\hline & - & - & - & - & - & - & - & - & & - & & - \\
\hline \multirow[t]{2}{*}{ I } & 0.516 & 0.963 & 0.841 & 0.449 & 0.484 & 0.222 & 0.120 & 0.286 & & 0.096 & 0.130 & 0.106 \\
\hline & - & - & - & - & - & - & - & - & & & & - \\
\hline \multirow[t]{2}{*}{$\mathbf{J}$} & 0.410 & 0.847 & 0.729 & 0.342 & 0.340 & 0.098 & 0.006 & 0.149 & 0.096 & & 0.228 & 0.027 \\
\hline & - & - & - & - & - & - & - & - & - & - & & \\
\hline \multirow[t]{2}{*}{ K } & 0.547 & 0.950 & 0.845 & 0.490 & 0.516 & 0.272 & 0.225 & 0.347 & 0.130 & 0.228 & & 0.175 \\
\hline & - & - & - & - & - & & & - & & & & \\
\hline \multirow[t]{2}{*}{$\mathrm{L}$} & 0.298 & 0.622 & 0.519 & 0.217 & 0.135 & 0.010 & 0.040 & 0.036 & 0.106 & 0.027 & 0.175 & \\
\hline & - & - & - & - & - & & & & & & & \\
\hline Toplam & 2.740 & 7.488 & 6.007 & 1.653 & 0.646 & 1.600 & 2.713 & 1.448 & 3.952 & 2.624 & 4.726 & 1.298 \\
\hline \multirow{2}{*}{$\begin{array}{l}\text { Ortalama } \\
\left(\mathrm{S}_{\mathrm{j}}\right)\end{array}$} & - & - & - & - & - & & & & & & & \\
\hline & 0.228 & 0.624 & 0.501 & 0.138 & 0.054 & 0.133 & 0.226 & 0.121 & 0.329 & 0.219 & 0.394 & 0.108 \\
\hline $\mathrm{S}_{\mathrm{c}}$ & 0.396 & 0.000 & 0.123 & 0.486 & 0.570 & 0.757 & 0.850 & 0.745 & 0.953 & 0.843 & 1.018 & 0.732 \\
\hline
\end{tabular}

Tablo 3'teki $\left(\mathrm{S}_{\mathrm{j}}\right)$ değerleri incelendiğinde. Eksenin başlangıç noktasını $(0)$ en küçük ölçek değerine kaydırmak için en küçük ölçek değerin $\left(\mathrm{S}_{\mathrm{j}}=-0.624\right)$ mutlak değeri diğer tüm ölçek değerlerine eklenerek yeni ölçek değerleri $\left(\mathrm{S}_{\mathrm{c}}\right)$ bulunmuştur ve Şekil 1'de gösterilmiştir.

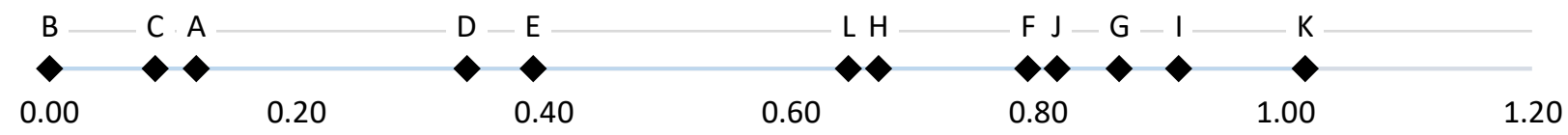

Şekil 1. Tüm Katılımcılardan Elde Edilen Ölçek Değerlerinin Sayı Doğrusu Üzerindeki Değerleri

Tablo 3'te gösterilen $\mathrm{Sj}$ uyarıcı sıralamalarına göre, bireylerin mutlu bir ilişkide partnerlerinden beklentileri Tablo 4'te gösterildiği şekilde sıralanmıştır.

Tablo 4.

Tüm Grup İçin Bireylerin Mutlu Bir Romantik İlişkide Partnerlerinden Bekledikleri Davranış/Durumlara İlişkin Ölçek Değerleri ve Sıralamalar

\begin{tabular}{lll}
\hline Davranış/durumlar & Sira Numaras1 & Ölçek Değerleri \\
\hline Sorumluluklarını yerine getirmesi (B) & 1 & 0.000 \\
Bana özgürlük alanı tanıyabilmesi (C) & 2 & 0.123 \\
Görgü ve nezaket kurallarına uygun davranması (A) & 3 & 0.396 \\
Ailem ile iyi ilişkiler kurabilmesi (D) & 4 & 0.486 \\
Yaptı̆̆ım hataları affedebilmesi (E) & 5 & 0.570 \\
İtiyaçlarımı kendi fark edip karşılaması (L) & 6 & 0.732 \\
Planlı ve düzenli bir şekilde yaşaması (H) & 7 & 0.745
\end{tabular}


İyi bir maddi gelire sahip olması (F)

8

0.750

Bana yeterince vakit ayırabilmesi $(\mathrm{J})$

9

0.843

İyi bir statüye sahip olması $(\mathrm{G})$

10

0.850

Kendi kişisel görünüşüne önem vermesi (I)

11

0.953

Günlük hayattaki sorunlara pratik çözümler üretebilmesi (K)

12

1.018

Tüm grup için katılımcıların mutlu bir romantik ilişkide partnerlerinden bekledikleri davranış/durumlara ilişkin ölçek değerleri Tablo 4'teki gibi sıralanmıştır. Araştırmaya katılanların verdikleri cevaplardan mutlu bir ilişkide partnerlerinden beklediği ilk üç davranış/durum sırasıyla "sorumluluklarını yerine getirmesi“, "bana özgürlük alanı tanıyabilmesi" ve "görgü ve nezaket kurallarına uygun davranması" olarak görülmektedir. Bu davranış/ durumları sırasıyla"ailemle iyi ilişkiler kurabilmesi”, "yaptığım hataları affedebilmesi", "ihtiyaçlarımı kendi fark edip karşılaması", "planlı ve düzenli bir şekilde yaşaması", "iyi bir maddi gelire sahip olmasıı","bana yeterince vakit ayırabilmesi”," "iyi bir statüye sahip olması","kendi kişisel görünüşüne önem vermesi" izlemektedir. Katılımcıların mutlu romantik ilişkide partnerlerinden bekledikleri durum/davranışlardan en son sıray "günlük hayattaki sorunlara pratik çözümler üretebilmesi" yer almıştır.

\section{İkinci araştırma sorusuna ait bulgular}

Türk katılımcılardan mutlu bir ilişkide partnerlerinden bekledikleri 12 tane davranış/durumları sıralamaları istenmiştir. Yapılan sıralama sonrası bu davranış/durumlara ilişkin frekans değerleri belirlenerek Tablo 5'te gösterilmiştir.

Tablo 5 .

Türk Katılımcılara Ait Sıra Frekanslar Matrisi (F)

\begin{tabular}{lllllllllllllll}
\hline $\mathrm{Ri}$ & ri & $\mathrm{A}$ & $\mathrm{B}$ & $\mathrm{C}$ & $\mathrm{D}$ & $\mathrm{E}$ & $\mathrm{F}$ & $\mathrm{G}$ & $\mathrm{H}$ & $\mathrm{I}$ & $\mathrm{J}$ & $\mathrm{K}$ & $\mathrm{L}$ & Toplam \\
\hline 1 & 12 & 12 & 1 & 1 & 2 & 2 & 30 & 8 & 5 & 6 & 3 & 7 & 36 & 113 \\
2 & 11 & 7 & 7 & 1 & 3 & 4 & 10 & 23 & 8 & 7 & 5 & 29 & 9 & 113 \\
3 & 10 & 4 & 5 & 11 & 5 & 6 & 9 & 10 & 9 & 9 & 24 & 7 & 14 & 113 \\
4 & 9 & 5 & 2 & 7 & 8 & 9 & 7 & 6 & 5 & 31 & 10 & 16 & 7 & 113 \\
5 & 8 & 7 & 4 & 5 & 5 & 6 & 5 & 4 & 31 & 10 & 16 & 10 & 10 & 113 \\
6 & 7 & 7 & 4 & 4 & 4 & 8 & 8 & 25 & 9 & 18 & 9 & 12 & 5 & 113 \\
7 & 6 & 9 & 5 & 3 & 6 & 11 & 17 & 12 & 16 & 11 & 13 & 5 & 5 & 113 \\
8 & 5 & 8 & 11 & 12 & 7 & 30 & 10 & 8 & 9 & 1 & 4 & 7 & 6 & 113 \\
9 & 4 & 6 & 10 & 14 & 23 & 21 & 3 & 5 & 7 & 9 & 3 & 4 & 8 & 113 \\
10 & 3 & 15 & 14 & 24 & 12 & 10 & 7 & 2 & 6 & 3 & 14 & 3 & 3 & 113 \\
11 & 2 & 15 & 27 & 16 & 17 & 2 & 4 & 7 & 3 & 5 & 5 & 8 & 4 & 113 \\
12 & 1 & 18 & 23 & 15 & 21 & 4 & 3 & 3 & 5 & 3 & 7 & 5 & 6 & 113 \\
\hline Toplam & & 113 & 113 & 113 & 113 & 113 & 113 & 113 & 113 & 113 & 113 & 113 & 113 & \\
\hline
\end{tabular}

Tablo 5'te görüldüğü gibi uyarıcı sayısı 12 olup sıra frekansları matrisinin her bir satır ve sütun elemanlarının toplamı. Toplam gözlemci sayısı olan 113'ü verir. Tablo 5'teki sira frekansları yardımıyla her bir uyarıcı için $n\left(S_{j i}>S_{k i}\right)=f_{j i} \cdot\left(f_{k<i}+(1 / 2) \cdot f_{k i}\right.$ denklemi yardımıyla frekanslar matrisi oluşturulmuştur. Her bir uyarıcıya ilişkin frekanslar matrisi oluşturduktan sonra bu matrislerin sütun toplamları yardımı ile elde edilen oranlar matrisi Tablo $6^{`}$ da sunulmuştur.

Tablo 6.

Türk Katılımcılara Ait Oranlar Matrisi (P)

\begin{tabular}{lllllllllllll}
\hline & $\mathrm{A}$ & $\mathrm{B}$ & $\mathrm{C}$ & $\mathrm{D}$ & $\mathrm{E}$ & $\mathrm{F}$ & $\mathrm{G}$ & $\mathrm{H}$ & $\mathrm{I}$ & $\mathrm{J}$ & $\mathrm{K}$ & $\mathrm{L}$ \\
\hline $\mathrm{A}$ & & 0.391 & 0.443 & 0.427 & 0.553 & 0.697 & 0.668 & 0.633 & 0.669 & 0.617 & 0.677 & 0.719 \\
$\mathrm{~B}$ & 0.609 & & 0.564 & 0.542 & 0.702 & 0.811 & 0.794 & 0.764 & 0.790 & 0.738 & 0.790 & 0.817 \\
$\mathrm{C}$ & 0.557 & 0.436 & & 0.483 & 0.655 & 0.784 & 0.766 & 0.725 & 0.756 & 0.700 & 0.766 & 0.796 \\
$\mathrm{D}$ & 0.573 & 0.458 & 0.517 & & 0.665 & 0.790 & 0.773 & 0.736 & 0.769 & 0.711 & 0.774 & 0.801 \\
$\mathrm{E}$ & 0.447 & 0.298 & 0.345 & 0.335 & & 0.712 & 0.698 & 0.646 & 0.695 & 0.621 & 0.705 & 0.736
\end{tabular}


Bireylerin Mutlu Bir Romantik İlişkide Partnerlerinden Beklediği Davranış/Durumların Sıralama Yargılarılla Ölçeklenmesi

\begin{tabular}{lllllllllllll} 
F & 0.303 & 0.189 & 0.216 & 0.210 & 0.288 & & 0.453 & 0.401 & 0.442 & 0.393 & 0.469 & 0.601 \\
G & 0.332 & 0.206 & 0.234 & 0.227 & 0.302 & 0.547 & & 0.442 & 0.488 & 0.433 & 0.533 & 0.601 \\
H & 0.367 & 0.236 & 0.275 & 0.264 & 0.354 & 0.599 & 0.558 & & 0.570 & 0.506 & 0.605 & 0.623 \\
I & 0.331 & 0.210 & 0.244 & 0.231 & 0.305 & 0.558 & 0.512 & 0.430 & & 0.453 & 0.557 & 0.623 \\
J & 0.383 & 0.262 & 0.300 & 0.289 & 0.379 & 0.607 & 0.567 & 0.494 & 0.547 & & 0.601 & 0.659 \\
K & 0.323 & 0.210 & 0.234 & 0.226 & 0.295 & 0.531 & 0.467 & 0.395 & 0.443 & 0.399 & & 0.582 \\
L & 0.281 & 0.183 & 0.204 & 0.199 & 0.264 & 0.460 & 0.399 & 0.343 & 0.377 & 0.341 & 0.418 & \\
\hline
\end{tabular}

Tablo 6'da görüldüğü gibi frekans matrislerindeki sütun toplamları toplam kişi sayısının karesine $\left(\mathrm{N}^{2}=113^{2}\right)$ bölünerek Tablo 7'deki oranlar matrisi elde edilmiştir. Bu oranlar matrisinin esas köşegene göre simetrik olan elemanlarının toplamı 1'i vermektedir.

Tablo 7.

Türk Katılımcılara Ait Birim Normal Sapmalar Matrisi (Z)

\begin{tabular}{|c|c|c|c|c|c|c|c|c|c|c|c|c|}
\hline & $\mathrm{A}$ & $\mathrm{B}$ & $\mathrm{C}$ & $\mathrm{D}$ & $\mathrm{E}$ & $\mathrm{F}$ & $\mathrm{G}$ & $\mathrm{H}$ & I & $\mathrm{J}$ & $\mathrm{K}$ & $\mathrm{L}$ \\
\hline & & - & - & - & & & & & & & & \\
\hline A & & 0.277 & 0.143 & 0.183 & 0.134 & 0.517 & 0.436 & 0.340 & 0.438 & 0.296 & 0.459 & 0.580 \\
\hline \multirow[t]{2}{*}{ B } & 0.277 & & 0.160 & 0.105 & 0.530 & 0.883 & 0.819 & 0.720 & 0.808 & 0.636 & 0.807 & 0.902 \\
\hline & & - & & - & & & & & & & & \\
\hline \multirow[t]{2}{*}{$\mathrm{C}$} & 0.143 & 0.160 & & 0.043 & 0.400 & 0.785 & 0.725 & 0.598 & 0.694 & 0.525 & 0.725 & 0.828 \\
\hline & & - & & & & & & & & & & \\
\hline \multirow[t]{2}{*}{$\mathrm{D}$} & 0.183 & 0.105 & 0.043 & & 0.425 & 0.805 & 0.750 & 0.630 & 0.736 & 0.558 & 0.751 & 0.846 \\
\hline & - & - & - & - & & & & & & & & \\
\hline \multirow[t]{2}{*}{$\mathrm{E}$} & 0.134 & 0.530 & 0.400 & 0.425 & & 0.561 & 0.518 & 0.375 & 0.511 & 0.308 & 0.540 & 0.631 \\
\hline & - & - & - & - & - & & - & - & - & - & - & \\
\hline \multirow[t]{2}{*}{$\mathrm{F}$} & 0.517 & 0.883 & 0.785 & 0.805 & 0.561 & & 0.118 & 0.252 & 0.145 & 0.272 & 0.078 & 0.257 \\
\hline & - & - & - & - & - & & & - & - & - & & \\
\hline \multirow[t]{2}{*}{$\mathrm{G}$} & 0.436 & 0.819 & 0.725 & 0.750 & 0.518 & 0.118 & & 0.147 & 0.030 & 0.169 & 0.082 & 0.257 \\
\hline & - & - & - & - & - & & & & & & & \\
\hline \multirow[t]{2}{*}{$\mathrm{H}$} & 0.340 & 0.720 & 0.598 & 0.630 & 0.375 & 0.252 & 0.147 & & 0.177 & 0.016 & 0.265 & 0.313 \\
\hline & - & - & - & - & - & & & - & & - & & \\
\hline \multirow[t]{2}{*}{ I } & 0.438 & 0.808 & 0.694 & 0.736 & 0.511 & 0.145 & 0.030 & 0.177 & & 0.117 & 0.143 & 0.313 \\
\hline & - & - & - & - & - & & & - & & & & \\
\hline \multirow[t]{2}{*}{$\mathrm{J}$} & 0.296 & 0.636 & 0.525 & 0.558 & 0.308 & 0.272 & 0.169 & 0.016 & 0.117 & & 0.256 & 0.410 \\
\hline & - & - & - & - & - & & - & - & - & - & & \\
\hline \multirow[t]{2}{*}{ K } & 0.459 & 0.807 & 0.725 & 0.751 & 0.540 & 0.078 & 0.082 & 0.265 & 0.143 & 0.256 & & 0.208 \\
\hline & - & - & - & - & - & - & - & - & - & - & - & \\
\hline \multirow[t]{2}{*}{$\mathrm{L}$} & 0.580 & 0.902 & 0.828 & 0.846 & 0.631 & 0.100 & 0.257 & 0.403 & 0.313 & 0.410 & 0.208 & \\
\hline & - & - & - & - & - & & & & & & & \\
\hline \multirow[t]{2}{*}{ Toplam } & 2.597 & 6.647 & 5.221 & 5.621 & 1.955 & 4.316 & 3.135 & 1.404 & 2.852 & 1.113 & 3.743 & 5.544 \\
\hline & - & - & - & - & - & & & & & & & \\
\hline Ortalama & 0.216 & 0.554 & 0.435 & 0.468 & 0.163 & 0.360 & 0.261 & 0.117 & 0.238 & 0.093 & 0.312 & 0.462 \\
\hline $\mathbf{S}_{\mathrm{c}}$ & 0.338 & 0.000 & 0.119 & 0.086 & 0.391 & 0.914 & 0.815 & 0.671 & 0.792 & 0.647 & 0.866 & 1.016 \\
\hline
\end{tabular}

Oranlar matrisindeki hücrelerde yer alan değerlere karşılık gelen birim normal değerler (z değerleri) elde edilmiş ve birim normal sapmalar matrisi (Z) Tablo 7'de gösterilmiştir. Matristeki z sütun değerlerinin ortalamaları alınarak 12' ye bölünmüş ve böylece ölçek değerleri (Sj) hesaplanmıştır. Tablo 7' deki $\left(\mathrm{S}_{\mathrm{j}}\right)$ değerleri incelendiğinde, eksenin başlangıç noktasını (0) en küçük ölçek değerine kaydırmak için en küçük ölçek değerin $\left(S_{j}=-0.554\right)$ mutlak değeri diğer tüm ölçek değerlerine eklenerek yeni ölçek değerleri $\left(S_{c}\right)$ bulunmuş ve Şekil 2'de gösterilmiştir.

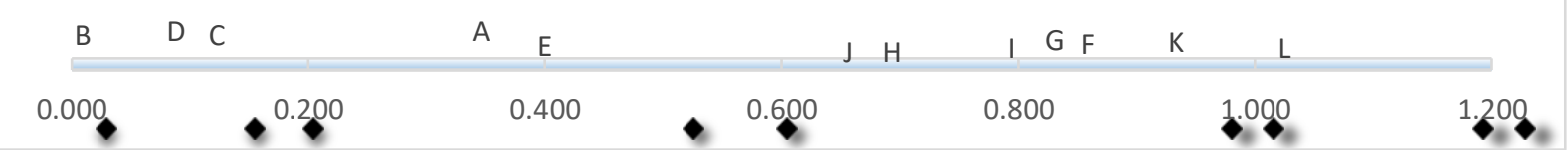


Şekil 2. Türk katılımcılardan elde edilen ölçek değerlerinin sayı doğrusu üzerindeki değerleri

Tablo 7'de gösterilen Sj uyarıcı sıralamalarına göre bireylerin mutlu bir ilişkide partnerlerinden bekledikleri davranış/durumlar Tablo 8'de gösterildiği şekilde sıralanmıştır.

Tablo 8.

Türk Katılımcıların Mutlu Bir İlişkide Partnerlerinden Bekledikleri Davranış/Durumlara İlişskin Ölçek Değerleri ve Sıralamalar

\begin{tabular}{lll}
\hline Davranış/durumlar & Sira Numarası & $\begin{array}{l}\text { Ölçek } \\
\text { Değerleri }\end{array}$ \\
\hline Sorumluluklarını yerine getirmesi (B) & 1 & 0.000 \\
Ailem ile iyi ilişkiler kurabilmesi (D) & 2 & 0.109 \\
Bana özgürlük alanı tanıyabilmesi (C) & 3 & 0.143 \\
Görgü ve nezaket kurallarına uygun davranması (A) & 4 & 0.189 \\
Yaptığım hataları affedebilmesi (E) & 5 & 0.400 \\
Bana yeterince vakit ayırabilmesi (J) & 6 & 0.672 \\
Planlı ve düzenli bir şekilde yaşaması (H) & 7 & 0.696 \\
Kendi kişisel görünüşüne önem vermesi (I) & 8 & 0.833 \\
İyi bir statüye sahip olması (G) & 9 & 0.840 \\
İyi bir maddi gelire sahip olması (F) & 10 & 0.892 \\
Günlük hayattaki sorunlara pratik çözümler & 11 & 0.941 \\
üretebilmesi(K) & & 1.200 \\
İhtiyaçlarımı kendi fark edip karşılaması (L) & 12 & \\
\hline
\end{tabular}

Türk katılımcıların mutlu bir romantik ilişkide partnerlerinden bekledikleri davranış/durumlara ilişkin ölçek değerleri Tablo 8'deki gibi sıralanmıştır. Araştırmaya katılanların verdikleri cevaplardan mutlu bir ilişkide partnerlerinden beklediği ilk üç davranış/durum sırasıyla "sorumluluklarını yerine getirmesi", "ailem ile iyi ilişkiler kurabilmesi" ve "bana özgürlük alanı tanıyabilmesi" olarak görülmektedir. Bu davranış/ durumları sırasıyla "görgü ve nezaket kurallarına uygun davranması","yaptığım hataları affedebilmesi","bana yeterince vakit ayırabilmesi”, "planlı ve düzenli bir şekilde yaşaması","kendi kişisel görünüşüne önem vermesi", "iyi bir statüye sahip olması", "iyi bir maddi gelire sahip olması", "günlük hayattaki sorunlara pratik çözümler üretebilmesi” izlemektedir. Katılımcıların mutlu bir ilişkide partnerlerinden beklediği davranışlardan en son sırada "ihtiyaçlarımı kendi fark edip karşılaması" yer almaktadır.

\section{Üçüncü araştırma sorusuna ait bulgular}

Amerikalı katılımcılardan mutlu bir ilişkide partnerlerinden bekledikleri 12 tane davranış/durumları sıralamaları istenmiştir. Yapılan sıralama sonrası bu davranış/durumlara ilişkin frekans değerleri belirlenerek Tablo 9'da gösterilmiştir.

Tablo 9.

Amerikalı Katılımcılara Ait Sira Frekanslar Matrisi (F)

\begin{tabular}{lllllllllllllll}
\hline Ri & ri & A & B & C & D & E & F & G & H & I & J & K & L & Toplam \\
\hline 1 & 12 & 7 & 3 & 6 & 15 & 5 & 1 & 5 & 6 & 6 & 2 & 20 & 10 & 86 \\
2 & 11 & 10 & 1 & 1 & 15 & 7 & 1 & 2 & 1 & 14 & 17 & 14 & 3 & 86 \\
3 & 10 & 2 & 2 & 4 & 2 & 8 & 5 & 8 & 7 & 17 & 19 & 8 & 4 & 86 \\
\hline
\end{tabular}




\begin{tabular}{lllllllllllllll}
\hline 4 & 9 & 2 & 2 & 1 & 6 & 6 & 5 & 12 & 12 & 19 & 9 & 6 & 6 & 86 \\
5 & 8 & 4 & 3 & 2 & 7 & 6 & 7 & 20 & 16 & 1 & 5 & 13 & 2 & 86 \\
6 & 7 & 2 & 1 & 2 & 7 & 10 & 10 & 17 & 8 & 8 & 11 & 8 & 2 & 86 \\
7 & 6 & 12 & 4 & 2 & 5 & 11 & 19 & 3 & 11 & 12 & 3 & 2 & 2 & 86 \\
8 & 5 & 2 & 1 & 3 & 8 & 18 & 11 & 6 & 12 & 2 & 16 & 5 & 2 & 86 \\
9 & 4 & 9 & 6 & 8 & 13 & 7 & 10 & 4 & 3 & 3 & 1 & 5 & 17 & 86 \\
10 & 3 & 8 & 14 & 24 & 4 & 3 & 10 & 1 & 5 & 1 & 1 & 1 & 14 & 86 \\
11 & 2 & 13 & 35 & 10 & 2 & 2 & 5 & 5 & 3 & 1 & 1 & 1 & 8 & 86 \\
12 & 1 & 15 & 14 & 23 & 2 & 3 & 2 & 3 & 2 & 2 & 1 & 3 & 16 & 86 \\
\hline Toplam & 86 & 86 & 86 & 86 & 86 & 86 & 86 & 86 & 86 & 86 & 86 & 86 & \\
\hline
\end{tabular}

Tablo 9'da görüldüğü gibi, uyarıcı sayısı 12 olup sıra frekansları matrisinin her bir satır ve sütun elemanlarının toplamı, toplam gözlemci sayısı olan 86'y1 verir.

Tablo 9ilesıra frekansları yardımıyla her bir uyarıcı için $n(S j i>S k i)=f j i .(f k<i+(1 / 2)$.fki denklemi yardımıyla frekanslar matrisi oluşturulmuştur. Frekanslar matrisini bulmak amacıyla sadece A uyarıcısı için frekanslar matrisi verilmiştir. Benzer şekilde diğer uyarıcılar için de frekanslar matrisi hesaplanır. En son K uyarıcısı için frekanslar matrisi sadece K $>$ L sütunundan oluşur. Her bir uyarıcıya ilişkin frekanslar matrisi oluşturduktan sonra bu matrislerin sütun toplamları yardımı ile elde edilen oranlar matrisi Tablo 10' da sunulmuştur.

Tablo 10.

Amerikalı katılımcilara ait oranlar matrisi(P)

\begin{tabular}{lllllllllllll}
\hline & $\mathrm{A}$ & $\mathrm{B}$ & $\mathrm{C}$ & $\mathrm{D}$ & $\mathrm{E}$ & $\mathrm{F}$ & $\mathrm{G}$ & $\mathrm{H}$ & $\mathrm{I}$ & $\mathrm{J}$ & $\mathrm{K}$ & $\mathrm{L}$ \\
\hline $\mathrm{A}$ & & 0.358 & 0.389 & 0.688 & 0.636 & 0.572 & 0.667 & 0.652 & 0.730 & 0.714 & 0.749 & 0.485 \\
$\mathrm{~B}$ & 0.642 & & 0.540 & 0.848 & 0.822 & 0.780 & 0.826 & 0.830 & 0.881 & 0.880 & 0.877 & 0.642 \\
$\mathrm{C}$ & 0.611 & 0.460 & & 0.808 & 0.783 & 0.731 & 0.787 & 0.787 & 0.841 & 0.840 & 0.843 & 0.603 \\
$\mathrm{D}$ & 0.312 & 0.152 & 0.192 & & 0.426 & 0.332 & 0.463 & 0.443 & 0.553 & 0.527 & 0.589 & 0.291 \\
$\mathrm{E}$ & 0.364 & 0.178 & 0.217 & 0.574 & & 0.394 & 0.568 & 0.530 & 0.673 & 0.639 & 0.689 & 0.325 \\
$\mathrm{~F}$ & 0.428 & 0.220 & 0.269 & 0.668 & 0.606 & & 0.689 & 0.644 & 0.787 & 0.755 & 0.785 & 0.321 \\
$\mathrm{G}$ & 0.333 & 0.174 & 0.213 & 0.537 & 0.432 & 0.311 & & 0.463 & 0.643 & 0.603 & 0.657 & 0.321 \\
$\mathrm{H}$ & 0.348 & 0.170 & 0.213 & 0.557 & 0.470 & 0.356 & 0.537 & & 0.672 & 0.631 & 0.676 & 0.250 \\
$\mathrm{I}$ & 0.270 & 0.119 & 0.159 & 0.447 & 0.327 & 0.213 & 0.357 & 0.328 & & 0.468 & 0.550 & 0.250 \\
$\mathrm{~J}$ & 0.286 & 0.120 & 0.160 & 0.473 & 0.361 & 0.245 & 0.397 & 0.369 & 0.532 & & 0.582 & 0.254 \\
$\mathrm{~K}$ & 0.251 & 0.123 & 0.157 & 0.411 & 0.311 & 0.215 & 0.343 & 0.324 & 0.450 & 0.418 & & 0.241 \\
$\mathrm{~L}$ & 0.515 & 0.358 & 0.397 & 0.709 & 0.675 & 0.606 & 0.679 & 0.676 & 0.750 & 0.746 & 0.759 & \\
& & & & & & & & & & & & \\
\hline
\end{tabular}

Tablo 10'da görüldüğü gibi frekans matrislerindeki sütun toplamları toplam kişi sayısının karesine $\left(\mathrm{N}^{2}=86^{2}\right)$ bölünerek P oranlar matrisi elde edilmiştir. Bu oranlar matrisinin esas köşegene göre simetrik olan elemanlarının toplamı 1'i vermektedir. Daha sonra Oranlar matrisindeki hücrelerde yer alan değerlere karşıllk gelen birim normal değerler (z değerleri) elde edilmiş ve birim normal sapmalar matrisi (Z) Tablo 11'de gösterilmiştir.

Tablo 11.

Amerikalı Katılımcilara Ait Birim Normal Sapmalar Matrisi (Z)

\begin{tabular}{lllllllllllll}
\hline & $\mathrm{A}$ & $\mathrm{B}$ & $\mathrm{C}$ & $\mathrm{D}$ & $\mathrm{E}$ & $\mathrm{F}$ & $\mathrm{G}$ & $\mathrm{H}$ & $\mathrm{I}$ & $\mathrm{J}$ & $\mathrm{K}$ & $\mathrm{L}$ \\
\hline & & - & - & & & & & & & & & - \\
$\mathrm{A}$ & & 0.365 & 0.282 & 0.489 & 0.348 & 0.181 & 0.433 & 0.390 & 0.614 & 0.565 & 0.671 & 0.037 \\
$\mathrm{~B}$ & 0.365 & & 0.101 & 1.029 & 0.925 & 0.773 & 0.940 & 0.953 & 1.179 & 1.177 & 1.161 & 0.363 \\
& & - & & & & & & & & & & \\
$\mathrm{C}$ & 0.282 & 0.101 & & 0.870 & 0.782 & 0.616 & 0.796 & 0.795 & 0.997 & 0.995 & 1.008 & 0.260 \\
& - & - & - & & - & - & - & - & & & & - \\
$\mathrm{D}$ & 0.489 & 1.029 & 0.870 & & 0.187 & 0.435 & 0.092 & 0.144 & 0.134 & 0.067 & 0.225 & 0.552 \\
& - & - & - & & & - & & & & & & - \\
$\mathrm{E}$ & 0.348 & 0.925 & 0.782 & 0.187 & & 0.269 & 0.170 & 0.076 & 0.449 & 0.357 & 0.493 & 0.453 \\
\hline
\end{tabular}




\begin{tabular}{|c|c|c|c|c|c|c|c|c|c|c|c|c|}
\hline $\mathrm{F}$ & $\begin{array}{l}- \\
0.181 \\
-\end{array}$ & $\begin{array}{l}- \\
0.773 \\
-\end{array}$ & $\begin{array}{l}- \\
0.616 \\
-\end{array}$ & 0.435 & $\begin{array}{l}0.269 \\
-\end{array}$ & - & 0.492 & $\begin{array}{l}0.370 \\
-\end{array}$ & 0.796 & 0.689 & 0.788 & $\begin{array}{l}- \\
0.466 \\
-\end{array}$ \\
\hline G & $\begin{array}{l}0.433 \\
-\end{array}$ & $\begin{array}{l}0.940 \\
-\end{array}$ & $\begin{array}{l}0.796 \\
-\end{array}$ & 0.092 & $\begin{array}{l}0.170 \\
-\end{array}$ & $\begin{array}{l}0.492 \\
-\end{array}$ & & 0.092 & 0.365 & 0.262 & 0.403 & $\begin{array}{l}0.466 \\
-\end{array}$ \\
\hline $\mathrm{H}$ & $\begin{array}{l}0.390 \\
-\end{array}$ & $\begin{array}{l}0.953 \\
-\end{array}$ & $\begin{array}{l}0.795 \\
-\end{array}$ & $\begin{array}{l}0.144 \\
-\end{array}$ & $\begin{array}{l}0.076 \\
-\end{array}$ & $\begin{array}{l}0.370 \\
-\end{array}$ & $\begin{array}{l}0.092 \\
-\end{array}$ & - & 0.446 & $\begin{array}{l}0.334 \\
-\end{array}$ & 0.455 & $\begin{array}{l}0.674 \\
-\end{array}$ \\
\hline I & $\begin{array}{l}0.614 \\
-\end{array}$ & $\begin{array}{l}1.179 \\
-\end{array}$ & $\begin{array}{l}0.997 \\
-\end{array}$ & $\begin{array}{l}0.134 \\
-\end{array}$ & $\begin{array}{l}0.449 \\
-\end{array}$ & $\begin{array}{l}0.796 \\
-\end{array}$ & $\begin{array}{l}0.365 \\
-\end{array}$ & $\begin{array}{l}0.446 \\
-\end{array}$ & & 0.080 & 0.126 & $\begin{array}{l}0.674 \\
-\end{array}$ \\
\hline $\mathrm{J}$ & $\begin{array}{l}0.565 \\
-\end{array}$ & $\begin{array}{l}1.177 \\
-\end{array}$ & $\begin{array}{l}0.995 \\
-\end{array}$ & $\begin{array}{l}0.067 \\
-\end{array}$ & $\begin{array}{l}0.357 \\
-\end{array}$ & $\begin{array}{l}0.689 \\
-\end{array}$ & $\begin{array}{l}0.262 \\
-\end{array}$ & $\begin{array}{l}0.334 \\
-\end{array}$ & $\begin{array}{l}0.080 \\
-\end{array}$ & - & 0.208 & $\begin{array}{l}0.662 \\
-\end{array}$ \\
\hline K & 0.671 & $\begin{array}{l}1.161 \\
-\end{array}$ & $\begin{array}{l}1.008 \\
-\end{array}$ & 0.225 & 0.493 & 0.788 & 0.403 & 0.455 & 0.126 & 0.208 & & 0.704 \\
\hline $\mathrm{L}$ & 0.037 & 0.363 & 0.260 & 0.552 & 0.453 & 0.269 & 0.466 & 0.457 & 0.674 & 0.662 & 0.704 & \\
\hline Toplam & $\begin{array}{l}- \\
3.007 \\
-\end{array}$ & $\begin{array}{l}- \\
8.966 \\
-\end{array}$ & $\begin{array}{l}- \\
7.300 \\
-\end{array}$ & 3.373 & 1.046 & $\begin{array}{l}- \\
2.000 \\
-\end{array}$ & 2.267 & 1.570 & 5.608 & 4.820 & 6.242 & $\begin{array}{l}- \\
4.066 \\
-\end{array}$ \\
\hline $\begin{array}{l}\text { Ortalama } \\
\mathrm{Sj}\end{array}$ & $\begin{array}{l}0.251 \\
0.496 \\
\end{array}$ & $\begin{array}{l}0.747 \\
0.000 \\
\end{array}$ & $\begin{array}{l}0.608 \\
0.139 \\
\end{array}$ & $\begin{array}{l}0.281 \\
1.028 \\
\end{array}$ & $\begin{array}{l}0.087 \\
0.834 \\
\end{array}$ & $\begin{array}{l}0.167 \\
0.580 \\
\end{array}$ & $\begin{array}{l}0.189 \\
0.936 \\
\end{array}$ & $\begin{array}{l}0.131 \\
0.878 \\
\end{array}$ & $\begin{array}{l}0.467 \\
1.214 \\
\end{array}$ & $\begin{array}{l}0.402 \\
1.149 \\
\end{array}$ & $\begin{array}{l}0.520 \\
1.267 \\
\end{array}$ & $\begin{array}{l}0.339 \\
0.408 \\
\end{array}$ \\
\hline
\end{tabular}

Tablo 11' deki $\left(\mathrm{S}_{\mathrm{j}}\right)$ değerleri incelendiğinde. Eksenin başlangıç noktasını $(0)$ en küçük ölçek değerine kaydırmak için. En küçük ölçek değerinin $\left(S_{j}=-0.724\right)$ mutlak değeri diğer tüm ölçek değerlerine eklenerek yeni ölçek değerleri $\left(\mathrm{S}_{\mathrm{c}}\right)$ bulunmuştur ve Şekil 1'de gösterilmiştir.

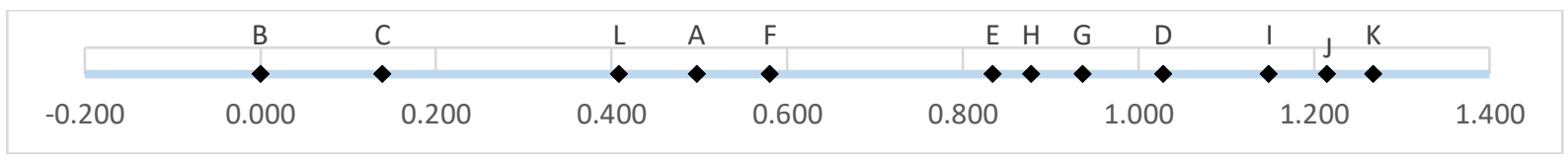

\section{Şekil 3.Amerikalı Katılımcıların Elde Edilen Ölçek Değerlerinin Sayı Doğrusu} Üzerindeki Ölçek Değerleri

Tablo 11'de gösterilen $\mathrm{Sj}$ uyarıcı sıralamalarına göre, bireylerin mutlu bir ilişkide partnerlerinden beklentileri Tablo 12' de gösterildiği şekilde sıralanmıştır.

Tablo 12.

Amerikalı Katılımcıların Mutlu Bir İlișkide Partnerlerinden Bekledikleri Davranıș/Durumlara İlişkin Ölçek Değerleri ve Sıralamalar

\begin{tabular}{lll}
\hline Davranış/durumlar & Sira Numaras1 & $\begin{array}{l}\text { Ölçek } \\
\text { Değerleri }\end{array}$ \\
\hline Sorumluluklarını yerine getirmesi (B) & 1 & 0.000 \\
Bana özgürlük alanı tanıyabilmesi (C) & 2 & 0.139 \\
İhtiyaçlarımı kendi fark edip karşılaması (L) & 3 & 0.408 \\
Görgü ve nezaket kurallarına uygun davranması (A) & 4 & 0.496 \\
Iyi bir maddi gelire sahip olması (F) & 5 & 0.580 \\
Yaptı̆̆ım hataları affedebilmesi (E) & 6 & 0.834 \\
Planlı ve düzenli bir şekilde yaşaması (H) & 7 & 0.878 \\
İyi bir statüye sahip olması (G) & 8 & 0.936 \\
Ailem ile iyi ilişkiler kurabilmesi (D) & 9 & 0.840 \\
Kendi kişisel görünüşüne önem vermesi (I) & 10 & 1.028 \\
Bana yeterince vakit ayırabilmesi (J) & 11 & 1.149 \\
Günlük hayattaki sorunlara pratik çözümler üretebilmesi & 12 & 1.214 \\
(K) & & \\
\hline
\end{tabular}

Amerikalı katılımcıların mutlu bir romantik iliskide partnerlerinden bekledikleri davranıș/durumlara ilișkin ölçek değerleri Tablo 12'deki gibi sıralanmıștır. Araștırmaya katılanların verdikleri cevaplardan katılımcıların mutlu bir ilişkide partnerlerinden beklediği ilk 
üç davranış/durum sırasıyla "sorumluluklarını yerine getirmesi”, "bana özgürlük alanı tanıyabilmesi” ve "ihtiyaçlarımı kendi fark edip karşılaması" olarak görülmektedir. Bu davranış/ durumları sırasıyla "görgü ve nezaket kurallarına uygun davranması", "iyi bir maddi gelire sahip olması", "yaptığım hataları affedebilmesi","planlı ve düzenli bir şekilde yaşaması","iyi bir statüye sahip olması","ailem ile iyi ilişkiler kurabilmesi”,"kendi kişisel görünüşüne önem vermesi","bana yeterince vakit ayırabilmesi” izlemektedir. Katılımcıların mutlu bir ilişkide partnerlerinden beklediği davranışlardan en son sırada"günlük hayattaki sorunlara pratik çözümler üretebilmesi” yer almıştır.

\section{Sonuç ve Öneriler}

Araştırma sonucunda iki farklı kültürden gelen katılımcılardan oluşan bireylerin mutlu bir romantik ilişkide partnerlerinden bekledikleri davranış/durumlardan en çok önemsenen üç davranış/durumun "sorumluluklarını yerine getirmesi", "bana özgürlük alanı tanıyabilmesi” ve "görgü ve nezaket kurallarına uygun davranması " olarak belirlenmiştir. Sorumluluklarını yerine getirebilme davranışı sorumluluk sahibi olma özelliği ile alan yazında eş seçmeyi etkileyen özellikler ile ilgili çalışmalarda ilk sıralarda olduğu görülmektedir (Efe, 2013; Langeroodi, Masoud ve Masoud, 2011). Katılımcılar için son üç sırayı "iyi bir statüye sahip olması", "kendi kişisel görünüşüne önem vermesi" ve "günlük hayattaki sorunlara pratik çözümler üretebilmesi" almıştır. Aslında literatürde "fiziksel görünüşün önemsenmesi” ilişkilerde özellikle erkekler için ön planda iken (MalachPines, 2001; Shipman, 2011; Soureh, 2011) bu çalışmada bu durumun son siralarda yer aldığ 1 görülmektedir.

Türk ve Amerikalı katılımcılar ayrı ayrı ele alındığında, hem sıralamada hem de ölçek değerlerinde farklılıklar oluşmuştur. Alan yazında da kültürlere göre romantik ilişki gelişiminin farklılaşabileceği savunulmakta olup (Huston ve Levinger, 1978), kültürler arası eş seçimi veya evlilik ile ilgili karşılaştırmalı çalışmalara yer verildiği olduğu görülmektedir (MalachPines, 2001; Schmitt, 2003). Türk katılımcılar için en çok önemsenen üç davranış/durum sorumluluklarını yerine getirmesi“", "ailem ile iyi ilişkiler kurabilmesi”, "bana özgürlük alanı tanıyabilmesi" iken, Amerikalılar için en çok önemsenen üç davranış/durum "sorumluluklarını yerine getirmesi”, "bana özgürlük alanı tanıyabilmesi" ve "ihtiyaçlarımı kendi fark edip karşılaması"olmuştur. İki ülke katılımcıları için en uzak sıralamalardan biri 'ailem ile iyi ilişkiler kurabilmesi' davranış/durumu belirlenmiştir. Türk bireyler bu özelliği çok önemserken, Amerikalı bireyler Türkler kadar önemsememiştir. Anıl ve Büyükatak (2019) çalışmalarında bireylerien çok mutlu eden faktörlerin başında "ailenin" geldiğini belirlemesi, aile faktörünün sadece romantik ilişkilerde değil tüm alanda kişiyi mutlu eden önemli bir faktor olduğunu göstermektedir.Türk katılımcıların en son iki sıraya yerleştirdiği iyi bir maddi gelire sahip olması ve ihtiyaçlarımı fark edip gidermesi davranış/durumlarını Amerikalı katılımcılar beşinci ve üçüncü sıralara yerleştirmişlerdir. Buna göre Türk katılımcılar tarafından önemsenmeyen iyi bir maddi gelire sahip olma ve ihtiyaçlarımı fark edip gidermesi davranış/durumları Amerikalı katılımcılar tarafından daha fazla önemsenmiştir. Bu sonuç ise Amerikalı bireyler için alan yazın ile benzerlik göstermektedir (Shipman 2011; Toro-Morn ve Sprecher, 2003).

$\mathrm{Bu}$ araştırma bireylerin romantik ilişkilerde partnerlerinden bekledikleri davranış/durumların belirlenmesi ve kültürler arası karşılaştırmalı analizler yapılması açısından oldukça orijinal bir çalışmadır. Fakat Türkiye ve Amerika'daki tüm bireyleri temsil edecek düzeyde bir örneklem sayısına sahip olmaması ise bu araştırmanın en önemli sınırlılığıdır. Gelecek çalışmalarda örneklem sayısı arttırılabilir veya yaş, ilişki memnuniyet durumu, eğitim düzeyi vb. farklı özelliklere sahip gruplara göre iki farklı kültürden bireylerin mutlu ilişki yaşamalarında etkili olduğu düşünülen davranış/durumlar incelenebilir. Ayrıca alan yazında mutlu romantik ilişkilerle ilgili yapılan çalışmalarda farklı ölçekleme yöntemlerinin uygulanması ve bu yöntemler sonucunda ortaya çıkan sonuçların karşılaştırılması önerilebilir.

\section{Kaynaklar}


Aluş, Y. (2016). Türk ailesinde eşler arası mutluluk algısı ve beklentileri: Sakarya ili örneği (Yayımlanmamış doktora tezi). Sakarya Üniversitesi Sosyal Bilimler Enstitüsü, Sakarya.

Anıl, D. ve Büyükatak, E. (2019). Bireylerin mutluluk faktörlerinin ikili karşılaştırmalar yöntemiyle ölçeklenmesi. Curr Res Educ, 5(1), 13-22.

Anıl, D. ve Güler, N. (2006). İkili karşılaştırma yöntemiyle ölçekleme çalışmasına bir örnek. Hacettepe Üniversitesi Eğitim Fakültesi Dergisi, 30, 30-36.

Anıl, D. ve İnal, H. (2017). Psikofizikte ölçekleme uygulamaları. Ankara: Pegem Akademi.

Aydoğdu. İ. (2010). Romantik ilişkilerin kişilik özellikleri açısından incelenmesi. (Yayımlanmamış yüksek lisans tezi). Gazi Üniversitesi, Ankara.

Bal, Ö. (2011). Seviye belirleme sınavı (SBS) başarısında etkili olduğu düşünülen faktörlerin sıralama yargıları kanunuyla ölçeklenmesi. Eğitimde ve Psikolojide Ölçme ve Değerlendirme Dergisi, 2(2), 200-209.

Bozgeyikli, H., Derin, S.ve Toprak, E. (2016). Üniversite öğrencilerinin mesleki değer algıları. Uluslararası Güncel Eğitim Araştırmaları Dergisi (UGEAD), 2(1), 139-156

Bozgeyikli, H. ve Toprak, E. (2013). Üniversiteli gençlerin eş seçim kriterlerinin suralama yargılarına göre ölçeklenmesi. Gençlik Araştırmaları Dergisi, 1(1), 68-87.

Collins, W. A. (2003). More and myth: the developmental significance of romantic relationships during adolescence. Journal of Research on Adolescence. 13(1), 1-24.

Creasey. G.. Kershaw. K. ve Boston. A. (1999). Conflict management with friends and romantic partners: The role of attachment and negative mood regulation expectancies. Journal of Youth and Adolescence. 28(5), 523-543.

Doğan, T. (2013). Beş faktör kişilik özellikleri ve öznel iyi oluş. Doğuş Üniversitesi Dergisi, 14(1), 56-64.

Dunn-Runkin, (1982). Scaling methods. New Jersey: Lawrence Erlbaum Associates Publishers.

Efe, E. (2013). Üniversite öğrencilerinin eş seçme eğilimleri (Yüksek lisans tezi). Hacettepe Üniversitesi, Eğitim Bilimleri Anabilim Dalı, Ankara.

Farabi, (1993). Mutluluk yoluna yöneltme (çev. Hanifi Özcan). İzmir

Fromm, E. (2003). Sevme sanatı. (S. Koçak ve D. Yay. Çev.). İstanbul: Payel Yayınları.

Furstenberg, F. F. Jr. (2010). On a new schedule: Transitions to adulthood and family change. Future of the Children, 20(1), 67-87.

Gilman, R., Huebner, E. S. ve Laughlin, J. E. (2000). A first study of the Multidimensional Students' Life Satisfaction Scale with adolescents. Social Indicators Research, 52(2), 135-160.

Guilford, J. P. (1954). Psychometrics methods. New York: Mc Graw-Hill Book Co.

Güler, N. ve Anıl, D. (2009). Scaling through pair-wise comparison method in required characteristics of students applying for post graduate programs. International Journal of Human Sciences, 6(1), 627-639.

Hazan, C. ve Zeifman, D. (1999). Pair-bonds as attachments: evaluating the evidence. J. Cassidy ve P. R. Shaver (Yay. haz.). Handbook of Attachment Theory and Research içinde (ss. 336-354). New York: Guilford.

Hoyt, L. L. ve Hudson, J. W. (1981). Personal characteristics important in mate pereferences among college students. Social Behavior and Personality: An International Journal, 9(1), 93-96.

Huston, T. L. ve Levinger, G. (1978). Interpersonal attraction and relationships. Annual Review of Psychology, 29, 115-156.

Karasar, N. (2013). Bilimsel araştırma yöntemi. Ankara: Nobel Yayın Dağıtım.

Kocadere, M. (1995). Iyy ve kötü evliliklerin özelliklerini belirlemeye yönelik betimsel bir çalısma.(Yüksek lisans tezi), Ege Üniversitesi Sağlık Bilimleri Enstitüsü, İzmir.

Langeroodi, R. R., Masoud, A. ve Masoud, H. (2011). The investigation of biological and psychological of marriage criteria from the view points of Iranian University students with that of their parents. Procedia - Social and Behavioral Sciences, 28, 406-410.

Myers, D. G. ve Diener, E. (1995). Who is happy? Psychological Science, 6(1), 10-19. 
Osmond, M. W. (1977). Marital organization in low-income families: a cross- race comparision. International Sociology of the Family, 7, 143-156.

Özkan, M. ve Arslantaş, H. İ. (2013).Etkili öğretmen özellikleri üzerine sıralama yöntemiyle bir ölçekleme çalışması. Trakya Üniversitesi Sosyal Bilimler Dergisi, 15(1), 311-330.

Malach Pines, A. (2001). The role of gender and culture in romantic attraction. European Psychologist, 6(2), 96-102.

Revenson, T. A., Kayser. K. ve Bodenmann. G. (2005). Couples coping with stress: Emerging perspectives on dyadic coping. Washington. DC: American Psychological Association.

Schmitt, D. P. (2003). Universal sex differences in the desire for sexual variety: tests from 52 nations. 6 continents. and 13 islands. Journal of Personality and Social Psychology, $85(1), 85-104$.

Shipman, C. S. A. (2011). Mate selection in modern India (Doctoral dissertations). University of Connecticut, ABD.

Soureh, N. F. (2011). Türk ve Iranl üniversite öğrencilerinin eş seçimi ile ilgili görüşleri (Yayımlanmamış yüksek lisans tezi). Gazi Üniversitesi Eğitim Bilimleri Enstitüsü, Ankara.

Sternberg, R. J. (1986). Understanding and increnning Lapr intelligence. San Diego: Rarcourt. Brace, Jovanovich.

Stevens, S. S. (1966). Handbook of experimental psychologhy. New York: John Willey and Sons.

Toro-Morn, M. ve Sprecher, S. (2003). A cross cultural comparison of mate preferences among university students: The United States vs. the People's Republic of China (PRC). Journal of Comparative Family Studies, 34(2), 151-170.

Tuncer, M. (2006). Aristo ve Farabi'de mutluluk düşüncesi (Yayınlanmamış yüksek lisans tezi), Cumhuriyet Üniversitesi, Sivas.

Turgut, M. F. ve Baykul, Y. (1992). Ölçekleme teknikleri. Ankara: ÖSYM Yayınları.

Türkben, Y.(2010). Descartes'1n ahlâk ve mutluluk anlayışı. Hikmet Yurdu (ASOS), 3(5), 239250.

Uraz, G. (1979). Müstakbel eşten beklentiler üzerine bir inceleme (Yayımlanmamış yüksek lisans tezi). Hacettepe Üniversitesi, Ankara.

Yıldırım, İ. (2007). Üniversite öğrencilerinin eş seçme kriterleri. Türk Psikolojik Danışma ve Rehberlik Dergisi, 3(27), 15-30.

\section{Extended Abstract \\ Introduction}

Happiness which is the fundamental need of human beings has the potential that may effect and make a difference on every moment of life (Gilman, Huebner \& Laughlin, 2000). Especially humans cannot live alone and have a close relationship with others. That is why happiness has also a direct effect on that relationship established by individuals. One of those close relationships is the romantic relationships with partners which have an important place on individuals' life. Based on the definition of happiness, a happy romantic relationship can be defined as a relationship that is wanted to live in which positive feelings are felt and inner peace is attained.

The happy romantic relationships established between individuals are conceptualized as a usually freely chosen relationship depicted by passion, attachment and intimacy (Sternberg, 1986). In a happy romantic relationship, it is one of the most important and fundamental issues that couples satisfy each other since it can be said that the happiness in relationships contributes more to general happiness than on the other sides of the life. Since each individual has a unique nature, individuals' expectations from their partners may be different in a happy relationship. While some people may prefer to be embraced, others want to be freer. While some individuals keep attraction at the forefront, others may prefer a partner who has a career life. All of those demands are shaped based on the experiences which individuals had in life process (Aydoğdu, 2010). As a result, in a happy relationship, behaviors or circumstances that partners expect from each other may also vary from situation to situation, even from person to person like happiness phenomenon. 
Studies about the happy marriages and characteristics that individuals pay attention on the choice of spouse are noteworthy in the literature (Efe, 2013; Kocadere, 1995; Osmond, 1977; Toro-Morn \& Sprecher, 2003). When the literature is examined, it is realized that the pre-marriage romantic relationships are less focused topics. However, it was seen that young people, nowadays, have spent more time on pre-marriage romantic relationships compared to the last years (Furstenberg, 2010). It is emphasized that one of the most frequently encountered problems on the adults who needs of psychological help is relationship problems (Revenson, Kayser \& Bodenmann, 2005). However, there are no studies found in the literature which is focusing on the expected behaviors from partners on a happy romantic relationship.

The main purpose of the scaling which arises on psychophysics which is a sub-branch of psychology is to establish a connection between the stimuli's measured and perceived characteristics (Dunn-Runkin, 1982; Guilford, 1954). Scaling method is used to identify the expected situations/behaviors from partners in a happy romantic relationship and to make a quantitative comparison between physical world and the perception world. Because the relationship between the perceived magnitude and the real magnitude is expressed quantitatively only with the help of scaling (Anil \& İnal, 2017). In the context of this study, behaviors that individuals expect from their partners in a happy romantic relationship were sought and scaled based on rank-order judgments scaling method. In addition to that, in order to see the similarities and differences between cultures, it was investigated that how Turkish and American people order behaviors that individuals expect from their partner in a happy relationship. With this purpose, answers for the following research questions were sought:

- What are the scale values and rank values for behaviors/situations which individuals expect from their partners in a happy relationship?

- What are the scale values and rank values for behaviors/situations which individuals expect from their partners in a happy relationship for Turkish participants?

- What are the scale values and rank values for behaviors/situations which individuals expect from their partners in a happy relationship for American participants?

\section{Method}

This study is a descriptive study since it does not include a generalization from sample information to a population and intends to describe the present situation as it is (Karasar, 2013). It was carried out with American and Turkish participants that could be reached within the age of 20-39. As a result, the study consisted of 86 American and 113 Turkish (in total 199) participants.

With the purpose of scaling behaviors/situations which individuals expect from their partners in a happy romantic relationship according to rank-order scaling method, a data collection tool which consist of two parts (Turkish and English) was developed in the process of research. First part includes the demographic information while the second part consists of 12 behavior/situation items which individuals expect from their partners in a happy relationship. In data collection tool development process, a pilot application was performed with 20 people consisting of Turkish and American participants who were in the age range determined in the main study. During that pilot study, participants were asked to list the behaviors/situations which individuals expect from their partners in a happy romantic relationship. Obtained answers and the literature (Efe, 2013; Hoyt \& Hudson ,1981; Kocadere, 1995; Osmond, 1977; Toro-Morn \& Sprecher, 2003; Uraz, 1979) were examined and the 12 behaviors/situations which are thought to be the most important of the behaviors / situations that individuals expect from their partners in a happy relationship were determined. Those 12 behaviors/situations were transformed into an application format that can allow the ordering of those factors such that the most important one as 1 and the most unimportant as 12. Data collection tool was examined in terms of meaning and content by an educational sciences expert group consisting of two educational measurement and evaluation expert. After necessary corrections, data collection tool took its final form. All of the data were analyzed with rank-order scaling method and scale values were obtained with Microsoft Excel software. In data analysis, firstly frequency values of the individuals' rankings were determined and the frequency matrix (F) was formed. For each stimulus, frequency matrix was 
determined and after that ratio matrix $(\mathrm{P})$ was constructed. In the next step, unit normal deviation matrix was obtained by determining the standard values $(\mathrm{Z})$ corresponding to the cell values $(\mathrm{P})$ on ratio matrix. Finally, scale values $\left(S_{j}\right)$ were calculated and $S_{j}$ values were shifted so that the smallest $S_{j}$ value is zero, and $S_{c}$ values were found (An1l \& İnal, 2017).

\section{Results and Discussion}

At the end of the study, obtained scale values were examined and it was found that for the total group of participants from two different cultures, which were considered to be identical gender, age and relationship status distributions, the three most important behaviors which individuals expect from their partners in a happy relationship are "fulfill his/her responsibilities", "give me a space for freedom" and "acting in accordance with the rules of manners and courtesy". "The ability to fulfill the responsibility" behavior is in the first places at the studies focusing on the factors affecting spouse selection in the literature (Efe, 2013; Langeroodi, Masoud \& Masoud, 2011). The three least important factors for the total group are; "to have a good status", "give importance to his/her personal appearance" and "produce practical solutions to the problems faced in daily life". Actually, literature indicates that "care for physical appearance" is important in relationships especially for men (Malach Pines, 2001; Shipman, 2011; Soureh, 2011). However, it was in last places in the context of that research.

When Turkish and American participants were separately evaluated, there were some differences on both rankings and scale values. In the literature, it is stated that the development of romantic relationships may differ according to cultures (Huston \& Levinger, 1978) and it is seen that there are comparative studies related to intercultural spousal selection or marriage (Malach Pines, 2001; Schmitt, 2003). The three most important behavior for Turkish participants were; "fulfill his/her responsibilities", "establish good relationships with my family" and "give me a space for freedom". On the other hand, the three most important behavior for Americans were; "give me a space for freedom", "respects my personal freedom/space" and "realizes my needs and meets them".

One of the furthest rankings for two countries was identified for the behavior which was "establish good relationship with my family". While it was very important for Turkish participants, Americans did not give importance as much as Turkish people did. The "have a good financial income" and "realizes my needs and meets them" behaviors/situations which were placed into the last two places by Turkish people were placed into fifth and third places by the American people. According to this finding, "have a good financial income" and "realizes my needs and meets them" behaviors/situations which were not minded by Turks were cared more by Americans. Those results are similar to the literature for American people (Toro-Morn \& Sprecher, 2003; Shipman 2011).

This study is quite original since it determined the behaviors/situations that individuals expect from their partners in romantic relationships and performed cross-cultural comparative analyses. However, the most important limitation of that study was that it was carried out with the individuals within the specified age range and was accessible from both countries within a specified time-period. That research could be replicated with a sample which has more representation power. According to the differences on age, relationship status, relationship satisfaction status, occupation and gender, the behaviors / situations that may affect the happiness of individuals from two different cultures could be examined separately. Besides, the application of several scaling methods on the studies related to happy romantic relationships and the comparison of those results may be suggested. 